\title{
An Attempt of Eradication of Respiratory Diseases in Breeding Mice by Sanitary Improvement of Care
}

\author{
Teruo MAGARIBUCHI*, Taeko FUKUDA, and Kaoru KOSHIMIZU \\ Division of Animal Research, Faculty of Medicine, University of \\ Tokyo, Hongo, Bunkyo-ku, Tokyo 113, Japan
}

(Received for publication : April 15, 1981)

\begin{abstract}
An attempt was made to eradicate respiratory diseases developed in about 1,000 mice of 19 congenic inbred strains which were maintained in a mouse breeding room. The contagious diseases with respiratory signs were found to be caused by mixed infections with Mycoplasma pulmonis and Sendai virus. The eradication of the diseases was mainly made by sanitary improvement in care of the mice such as intensive disinfection, culling some diseased mice and so on, instead of destroying all colonies. As the result, mycoplasma infection decreased gradually, resulting in a complete eradication about one and half years later and remarkable increases in litter size and weaning rate of mice were obtained. Sendai virus infection failed to be eradicated.
\end{abstract}

\section{繁殖用マウスの衛生的飼育管理の改善による呼吸器病撲滅の試み}

\author{
曲淵輝夫・福田妙子・舆水 馨
}

東京大学医学部附属動物実験施設

近年, 実験動物の繁殖あるいは実験施設においてバリ アシステムなど飼育施設の改善により，感染病を未然に 防ぐ努力がはらわれている。しかし，いったん施設内に 病原体の侵入をゆるすとその撲滅は甚だ困難であり, コ ロニーの閉鎖または実験の中止などを余儀なくされてい るのが現状である。

当施設においてはコンジェニックの近交系マウスが数 多く使用されているが，1979年 1 月にこれらのマウスに 呼吸器症状を主徵とする感染病が発生した。しかし, 貴 重なコンジェニック・マウスは入手が困難なため, これ らのマウスをすべて淘汰することができなかった。そこ で,われわれはマウスの系統維持を続けながらこの感染 病を排除することを計画し, 徹底した衛生的飼育管理を とることにより清浄化を試みたのでその成績について報 告する。

\section{材料および方法}

供試マウス：検索に供したマウスは以下に示す19系統 のコンベンショナル 動物, 計 1, 474 匹であった。C $3 \mathrm{H}$. SWIga (CSW), C3H. SWIgb (CWB), B10. A (2 R), B10. A (3 R), B10.A (5R), B10.BR/Sgsn, B10.S, A. TH, A. TL, A/Sn, A/J, AKR, BALB/c, C3H/He, $\mathrm{CBA}, \quad \mathrm{DBA} / 2 \mathrm{~N}, 129 / \mathrm{J}, \quad \mathrm{BALB} / \mathrm{c} \times \mathrm{B} 10 . \mathrm{A}(3 \mathrm{R})$, $\mathrm{CSW} \times \mathrm{BALB} / \mathrm{c}$ 。

隔離前の飼育管理 : 飼育にはアルミニウム製 $(17 \mathrm{w} \times$ $\left.30^{\mathrm{D}} \times 11^{\mathrm{H}} \mathrm{cm}\right)$ ケージを使用し，市販固型飼料 CMF， $\mathrm{NMF}, \mathrm{MF}$ (オリエンタル酵母) および非滅菌水道水 を自由に摄取させた。飼育室は面積 $21 \mathrm{~m}^{2}$, 温度 $23 \pm$ $1^{\circ} \mathrm{C}$, 湿度 $55 \pm 5 \%$ で, 平均約 1,000 匹のマウスが常時

* Present address : Biological Research Laboratories, Sankyo Co. Ltd, No. 2-58, 1-Chome, Hiromachi, Shinagawa-ku, Tokyo 140 
繁殖・維持され，これらのマウスの一部を用いて同じ飼 育室内で動物実験が行われていた。この飼育室内の入室 には特に制限は実施しなかった。

隔離後の飼育管理：1979年の 6 月末に新しく飼育面積 $21 \mathrm{~m}^{2}$ の 3 室が確保されたのを機会に 感染病を排除する ため，基本的な衛生管理の徹底に重点をおき飼育環境の 整備を実施した。すなわち，1）温度, 湿度は隔離前と 同じ条件であるが，系統維持群と実験群を別々の室に完 全に隔離した。2）疾病が疑われるマウスはできるだけ 淘汰した。3）繁殖室の出入りを飼育管理者だけに制限 した。4）入室時には専用の衣服, 帽子, 手袋, マスク およびスリッパの使用を励行した。5）手指の消毒（200 倍マイクロカット), 室の消毒 (500 倍ピューラックス) および清掃を徹底した。6）乘菌灯（東芝殺菌ランプ 10 $\mathrm{W} 4$ 個）を作業時以外は常時点灯した。7）マウスの健 康状態の観察と記録を徹底した。

分離培地：マイコプラズマの分離用液体培地は, 先に 報告[9]したよ5に，PPLO broth (Difco) に無菌馬血 清を $20 \%, 25 \%(w / v)$ イーストエキストラクト（日甜） を $10 \%, 10$ 万単位 $/ \mathrm{m} l$ のペニシリン $\mathrm{G}$ (万有製薬）を 1 $\%, 2.5 \%$ 酥酸タリウム（和光純薬）を $1 \%$ さらに指示 薬として $0.2 \%$ フェノールレッドを $0.5 \%$ およびグルコ ースを $0.5 \%$ の割合に添加したものを $10 \% \mathrm{NaOH}$ で $\mathrm{pH}$ 7.8 に調整した。また固形培地は上記液体培地よりフェ ノールレッドとグルコースを除き Bacto agar (Difco) を $1.2 \%$ の割合に添加した。一般細菌の分離には $5 \%$ 馬 血液加トリプチィックソイ 寒天（Difco）培地を使用し た。

分離方法：マイコプラズマの分離には，鼻腔および咽 喉頭の粘膜を滅菌スワブによりぬぐい取り， $2 \mathrm{ml}$ の PPLO broth に接種した。肺は全葉を無菌的に取り出 し, 病変の有無を肉眼で観察したのち，20倍 $(\mathrm{v} / \mathrm{w})$ の PPLO broth を加えホモジナイザーで乳剂とし，3，000 $\mathrm{rpm} 5$ 分遠沈後上清 $0.3 \mathrm{~m} l$ を 10 倍段階希䣋し前記液体 培地 $2.7 \mathrm{~m} l$ に接種した。培養は $37^{\circ} \mathrm{C}$ で 7 日間行い, $\mathrm{pH}$ の変化で培地の色調が黄変した試験管から 1 白金耳量を 固形培地に塗布した。固形培地は湿度を保った条件下で $37^{\circ} \mathrm{C} 7$ 日間好気培養を行い, 実体顕微鏡によりマイコ プラズマ集落発育剤の有無を観察した。一般細菌分離の ためには上記材料を直接 $5 \%$ 馬血液加トリプチィックソ イ寒天培地に塗抹接種し $37^{\circ} \mathrm{C}$ で 48 時間培養した。

マイコプラズマ株：マイコプラズマは東京大学農学部 家畜微生物学教室の 尾形学教授より分与を 5 けた $M$. pulmonis m 53 株 および M. neurolyticum PG 28 株
を用いた。

マイコプラズマの同定：m53ならびに PG 28 株に対 するウサギ免疫血清を用いディスク法による発育阻止試 験[5]によって同定した。

血清反応：M. pulmonis 抗体の検索には補体結合 (CF) 反応を，センダイウイルス抗体の検索には血球凝 集阻止 (HI) 反応を，それぞれマイクロタイター法で実 施した。CF 反応の抗原は，M. pulmonis m 53 株の大 量培養菌液を $9,000 \mathrm{rpm} 60$ 分遠沈後, 得られた 沈渣を 原菌液量の 100 倍に濃縮して $-20^{\circ} \mathrm{C}$ に保存し, 使用前に $100^{\circ} \mathrm{C} 10$ 分間加熱して使用した。反応は Kolmer の変 法[14]に準拠した。

HI 反応の抗原は実験動物中央研究所の 岩井 汯博士 より分与をらけた HVJ-MN 株感染ふ化嗂卵尿液エー テル不活化抗原を用いた。

被検血清は非特異反応を除去するため, Saito ら [12] の方法によりニワトリ血球で処理した後検査に供した。 また HI 反応に使用した希釈液 (PBS) にはニワトリ血 漿を $56^{\circ} \mathrm{C} 30$ 分加温し， $3,000 \mathrm{rpm}$ 15分遠沈した上清を $1 \%$ の割合に加えた。CF 反応および $\mathrm{HI}$ 反応ともに陽 性限界を $1: 10$ とした。

産仔数と離乳率：繁殖は倠雄 $1: 1$ の同居方式で行い 産仔は生後18日目に離乳させた。産仔数は出生時確認で きた 1 腹当りの仔数で, 離乳率は産仔数に対する離乳仔 数の比で表わした。

\section{成}

1. 疾病の発生状況

1978年の 9 月から12月の間, 繁殖室内マウスについて の疾病の検査では, 臨床症状および肺の肉眼的病変は認 められず，鼻腔，咽搌頭，肺からはマイコプラズマおよ び病原細菌が検出されなかった。しかし1979年 1 月に呼 吸器症状を示す個体が発見され, 剖検したところ肺の肝 変化病変が認められた。鼻腔, 咽喉頭, 肺の細菌検査の 結果マイコプラズマが検出された。

2. 污染状況

1979年 1 月から 6 月までは呼吸器症状が散見され，一 部の個体を海汰した。この期間，主に外見上異常が認め られたもの 728 匹について肺病変の肉眼的観察, 肺から のマイコプラズマ分離, M. pulmonis に対する $\mathrm{CF}$ 抗 体およびセンダイウイルスに対する HI 抗体の検查を実 施した。Table 1 に示すよ5に肺に肉眼的病変が認めら れたものは $322 / 728(44.2 \%)$ であった。肺病変の大部 
Table 1. Detections of gross lung lesion, mycoplasma and antibodies against M. pulmonis and Sendai virus in mice from January to June, 1979

\begin{tabular}{|c|c|c|c|c|c|}
\hline \multirow{2}{*}{$\begin{array}{l}\text { Strain } \\
\text { of mouse }\end{array}$} & \multirow{2}{*}{$\begin{array}{l}\text { No. of } \\
\text { tested }\end{array}$} & \multirow{2}{*}{$\begin{array}{c}\text { Gross } \\
\text { lung lesion }\end{array}$} & \multirow{2}{*}{$\begin{array}{l}\text { Mycoplasma } \\
\text { isolation }\end{array}$} & \multicolumn{2}{|c|}{ Antibody positive to } \\
\hline & & & & M. pulmonis & Sendai virus \\
\hline CSW & 103 & 60 & 76 & 9 & 25 \\
\hline CWB & 24 & 11 & 23 & 7 & 5 \\
\hline B10. A (2 R) & 11 & 7 & 0 & 0 & 9 \\
\hline B10. A (3 R) & 10 & 7 & 8 & 6 & 3 \\
\hline B10. A (5 R) & 13 & 8 & 1 & 0 & 8 \\
\hline B10. BR/Sgsn & 4 & 0 & 0 & 0 & 2 \\
\hline B10.S & 19 & 7 & 1 & 0 & 11 \\
\hline A. TH & 7 & 7 & 5 & 1 & 1 \\
\hline A. TL & 7 & 4 & 5 & 0 & 5 \\
\hline $\mathrm{A} / \mathrm{Sn}$ & 42 & 34 & 4 & 0 & 13 \\
\hline $\mathrm{A} / \mathrm{J}$ & 23 & 13 & 0 & 5 & 12 \\
\hline AKR & 13 & 11 & 0 & 0 & 7 \\
\hline $\mathrm{BALB} / \mathrm{c}$ & 25 & 8 & 9 & 2 & 13 \\
\hline $\mathrm{C} 3 \mathrm{H} / \mathrm{He}$ & 51 & 11 & 21 & 14 & 44 \\
\hline $\mathrm{CBA}$ & 289 & 98 & 24 & 21 & 135 \\
\hline $\mathrm{DBA} / 2 \mathrm{~N}$ & 13 & 5 & 12 & 0 & 7 \\
\hline $129 / \mathrm{J}$ & 20 & 11 & 3 & 2 & 3 \\
\hline $\mathrm{BALB} / \mathrm{c} \times \mathrm{B} 10 . \mathrm{A}(3 \mathrm{R})$ & 29 & 11 & 24 & 0 & 10 \\
\hline $\mathrm{CSW} \times \mathrm{BALB} / \mathrm{c}$ & 25 & 9 & 18 & 9 & 22 \\
\hline Total & 728 & $322(44.2$ & $234(32.1 \%)$ & $76(10.4$ & \%) $335(46 \%)$ \\
\hline
\end{tabular}

Table 2. Isolation rate of mycoplasma from various sites in mice

\begin{tabular}{lcccc}
\hline \multicolumn{1}{c}{ Site } & No. of positive & / & No. of examined & $(\%)$ \\
\hline Nasal cavity & 184 & $/$ & 728 & $(25.2)$ \\
Oropharynx & 141 & $/$ & 728 & $(19.4)$ \\
Lung & 57 & $/$ & 728 & $(7.8)$ \\
\hline
\end{tabular}

分は一葉または全葉にわたる赤色肝变化病巣で，膿瘍は 認められなかった。マイコプラズマは鼻腔，咽喉頭およ び肺のいずれか 1 力所以上から検出されたものを陽性個 体とした場合，その分離率は， $234 / 728(32.1 \%)$ であ った。そのときの M. pulmonis CF 抗体陽性率は 76/ 728 (10.4\%) であり，またセンダイウイルス HI 抗体陽 性率は 335/728 (46\%) であった。Pasteurella sp., Corynebacterium kutscheri およびその他の病原細菌 は検出されなかった。

部位別のマイコプラズマ分離率は Table 2 に示すよ 5に鼻腔では $25.2 \%$, 咽喉頭 $19.4 \%$, 肺では $7.8 \%$ あ った。
Table 3. Identification of isolated mycoplasma

\begin{tabular}{lcc}
\hline \multicolumn{1}{c}{ Site } & M. pulmonis & M. neurolyticum \\
\hline Nasal cavity & $18^{*}$ & 3 \\
Oropharynx & 23 & 3 \\
Lung & 13 & 1 \\
\hline Total & 54 & 7 \\
\hline * Numbers of strains identified \\
分離したマイ コプラズマのうち61株について発育阻止 \\
試験により同定したところ, Table 3に示すように61株 \\
中54株は M. pulmonis, 残りの7 株は M. neuroly.
\end{tabular}



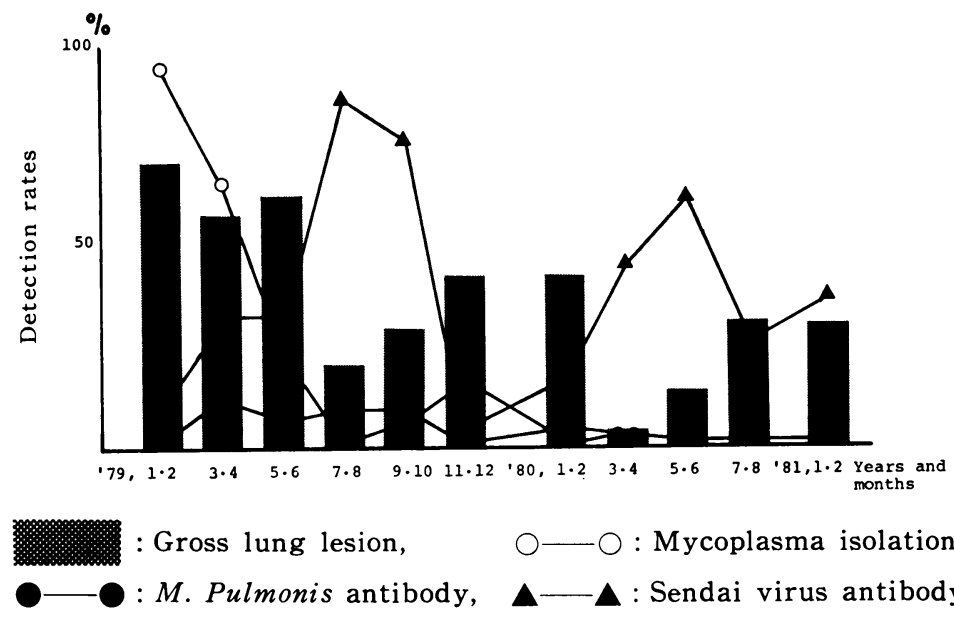

: Gross lung lesion,

$\bigcirc-\bigcirc:$ Mycoplasma isolation,

: Pulmonis antibody,

: Sendai virus antibody

Fig. 1. Sequential changes of detections of gross lung lesions, mycoplasma and $M$. pulmonis and Sendai virus antibodies in breeding mice

ticum と同定された。これらの両菌種は検索したいずれ の部位からも分離された。

A）防除対策前後に拈ける污染度の比較

繁殖群と実験群を隔離し, 飼育方法を改善した後も, 引き続き繁殖群に打ける疾病の検索を行った。その成績 は防除対策前に打ける繁殖群の污染状況の成績と併せて Fig. 1 に示す。肺病変出現率は, 感染が確認された1979 年 $1 \cdot 2$ 月がもっとも高く $12 / 17(70 \%)$ であり, その後 も $3 \cdot 4$ 月は, $74 / 127(58 \%), 5 \cdot 6$ 月は 55/86 (63\%) と高率であった。しかし，防除対策を開始した1979年 6 月以降の検査では， $7 \cdot 8$ 月が $37 / 174(21 \%) ， 9 \cdot 10$ 月 が $29 / 96$ (30\%)，11・12月が $13 / 30$ (43\%)，1980年 $1 \cdot 2$ 月が $9 / 21(43 \%)$ で多少の変動はあるものの防除対策開始 前に比べて減少の傾向を示し，さらに 同年 $3 \cdot 4$ 月には 6/141 (4\%)，5・6月には 23/158 (14\%) と減少した。 しかし，その後やや增加して $7 \cdot 8$ 月には 14/45 (31\%), 1981年 1・2月には $24 / 81(30 \%)$ であった。

マイコプラズマの分離率は, 対策以前の1979年 $1 \cdot 2$ 月 には $16 / 17(94 \%)$ と高率で，その後 85/127 (67\%), 22/86 (26\%) と多少 減少の傾向がみられた。しかし, 対策開始後1980年の7・8月までには0/174，4/96( $4 \%)$, $5 / 30(17 \%), 0 / 21 ， 1 / 141(0.7 \%) ， 0 / 158,0 / 45$ と極 端に減少し，1981年 $1 \cdot 2$ 月においてもなお $0 / 81$ と陰性 であった。

M. pulmonis の CF 抗体陽性率は対策前も全体に高 くはなかったが、マイコプラズマが分離されなくなった
1980年 $5 \cdot 6$ 月以降は抗体も陰性になり，対策後 1 年半 経過した 1981年 $1 \cdot 2$ 月の時点でも全く検出されなかっ た。

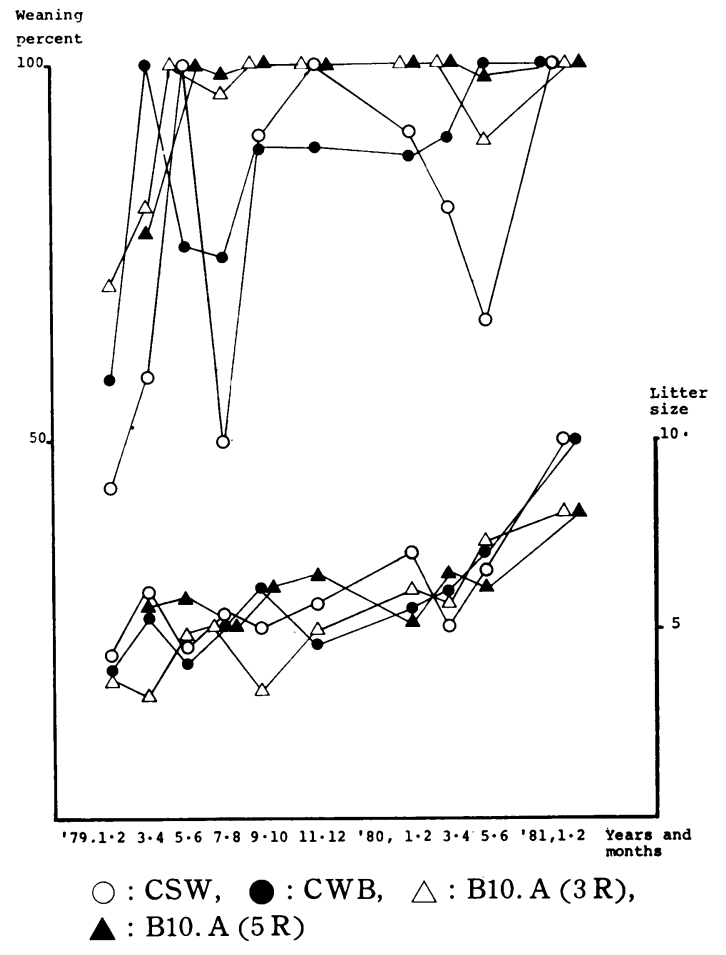

Fig. 2 Weaning percent and litter size in breeding mice 
センダイウイルの HI 抗体陽性率は経時的に変動がみ られた。すなわち肺病変出現率が低いときは抗体の陽性 率が高く, 肺病変出現率が高いときは抗体陽性率が低か った。

B) 産仔数と離乳率

Fig. 2 に示すよ5に 4 系統の マウスについて産仔数 々離乳率を詳細に検討した。産仔数は病気の流行初期に は各系統ともに平均約 4 匹であったが，清浄化対策を施 してからは徐々に增加し，1980年 $5 \cdot 6$ 月になると平均 約 7 匹になり，1981年 1・2 月には CSW，CWB は約 10匹，B10.A (3R)，B10.A (5 R) は約 8 匹になった。 また離乳率は B10. A (3R) および B10. A (5R)の 2 系 統は1980年 $5 \cdot 6$ 月で $100 \%$ に達し，その後継続的に高率 であった。CSW の離乳率は流行の初期には $42 \%$ とかな り低く，その後一時回復のきざしがみられたが，1980年 の前半には再び低下し，全体的に 変動が 激しかった。 CWB についても初めはかなり変動したが, 徐々に回復 し1980年 $5 \cdot 6$ 月には100\%になった。

\section{考察}

コンジェニック・マウスの繁殖コロニーにおいて呼吸 器症状を主徵とする感染病が発生し, 菌および抗体検索 の結果, M. pulmonis とセンダイウイルスの重複感染 によるものであることが判明した。しかしコンジェニッ ク・マウスは入手が困難であり全個体を淘汰し新しい種 親を搬入することは実験等の都合上できなかった。その ため感染病防除対策として種親を維持しつつ外見上異常 が認められる個体はできるだけ淘汰し，さらに衛生的飼 育管理の 徹底に 重点を置いて 飼育方法の 改善をはかっ た。その結果，マイコプラズマ感染に対しては，防除対 策前の検査では，94\%，67\%，26\%と高率に陽性個体が 検出されたが，対策後陽性個体は減少し 1 年半経過した 1981年 $1 \cdot 2$ 月の検查では菌分離はもちろん抗体陽性? ウスもまったく検出されなくなった。マイコプラズマの 感染様式について Atobe 5[1]は ICR 系マウスを用い た M. pulmonis の感染実験で接種後 1 年経過した時点 においても肺病変および菌の分離が認められ，また $\mathrm{CF}$ 抗体についても同様に約10ケ月存続していたと報告して いる。しかし一方 Brennan ら[4], Nikaido ら[10]の 報告のようにマウスの感受性の差あるいは $M$. pulmonis の病原性の強弱によってもその感染様式, 病変発現 等は異なるものと思われる。今回のマイコプラズマ感染 が自然消失したのかあるいはわれわれのとった処置だけ
で消失したのか定かではないが，少なくとも繁殖室内の マウスよりマイコプラズマが消失し，それによって飼 育・実験者に衛生的飼育管理の重要性を認識させた事は 確かである。

今回の調査では $M$. pulmonis と $M$. neurolyticum の 2 種類のマイコプラズマが鼻腔, 咽喉頭, 肺より分離 された。M. pulmonis の肺炎起病性に数多くの報告で 明らかにされているが， M. neurolyticum に関しては Atobe ら[2]はマウスより分離した株の経鼻接種実験で 呼吸器への定着は認められず, 肺炎形成之直接的関連は ないと記載している。今回, 同定した61株中54株が $M$. pulmonis で M. neurolyticum に比べ優位であったこ とから肺病変形成に関与していた因子はセンダイウイル スともに M. pnlmonis と考えられる。

マイコプラズマの分離部位は鼻腔がもっとも高く, 陽 性個体 234 匹中 184 匹 (79\%) から検出された。Atobe ら[2]および Saito 5[11]は，鼻腔，気管からのマイコ プラズマ分離が口腔，肺などより高率であったと報告し ている。マイコブラズマ污染を検索する場合, 血清学的 検索と併せ, これら部位の菌分離を同時に実施すれば, 摘発の効率がよくなると思われる。

センダイウイルス感染はわれわれがとった方法では完 全な除去はできず，感染は継続した。Iwai ら [8]は, ICRマウスコロニーのセンダイウイルス感染に批いて離 乳マウスや妊娠マウスを感染コロニーから隔離し別の飼 育室で管理すると抗体のないマウスが得られたことを報 告している。また Saitoら [13]は, ddY マウス繁殖コ ロニーに発生したセンダイウイルス感染において, ウィ ルスの排除を試み，感染が確認された時点で 4 週齢以下 の離乳仔と哺乳仔を一斉に殺処分し，また新しく生まれ た仔と臨床症状を示す種親を淘汰した結果, 繁殖コロニ 一からセンダイウイルスが排除できたことを報告してい る。われわれは異常個体の殺処分はできるだけ実行した が，ある一定期間繁殖を中止する方法はとることができ ずまを限られたスペースで多くの系統を維持せざるを えなかったため，センダイウイルス感染の除去ができな かったものと考えられる。

繁殖コロニー内にセンダイウイルス感染が起こると, 親マウスによる乳吞みマウスの喰殺が増加し，また妊娠 期間の延長, 離乳率の低下等のみられることが記載 $[3$, $6,7,8]$ されている。今回, 防除対策後に打ける清净化の ひとつの指標として産仔数および離乳率について検討し たところ，両者ともに著しく上昇した。このことは飼育 環境の改善によるものであろう。 
今回の呼吸器病流行にお忛る病原体の侵入経路につい ては不明であるが，その推移について考察してみると， はじめに $M$. pulmonis の不顕性感染がマウス繁殖室内 で起こり，ついでセンダイウイルスが侵入するとともに 病状が顕性化し，爆発的な流行になったものと考えられ る。この流行を助長したものは, 毎日室内に出入してい た不特定多数の実験者による衛生管理面での不徹底さで あったことは否定できない。このたび，われわれが経験 したマウス呼吸器病の発生は, 日常多数の実験者が出入 する施設においては常に起こりらる可能性があり，今後 とも警戒を意ってはならないと考える。

\section{要 約}

コンジェニック・マウスの繁殖群に呼吸器症状を主徵 とする感染病が発生した。そこで，マウスを全群淘汰す ることなしにこの感染病を防圧するため, 徹底した衛生 的飼育管理を行いマウスの清净化を試みた。得られた成 績を要約するとつぎのとおりである。1）呼吸器症状を 主徴とする感染病は, M. pulmonis とセンダイウイル スの混合感染によることが明らかにされた。2）徹底し た衛生的飼育管理によりマイコプラズマはほぼ完全に撲 滅できた。3）センダイウイルス感染は，この方法では 完全に排除はできず，感染は継続した。4）産仔数およ び離乳率は防除対策実施後著しく上昇した。

本研究において使用したマイコプラズマ菌株の分与を賜っだ 東大農学部の尾形学教授ならびにセンダイウイルス株および抗 原を分与いただいた実中研の岩井浤博士に謝意を表する。本研 究の一部は 昭和55年度文部省科学研究費 - がん特別研究費 No. 501047 および科学研究費補助金 (奖劯研究〔B]) によった。

\section{文献}

[1] Atobe, H., and Ogata, M. (1974). Pneumonitis in mice inoculated with Mycoplasma pulmonis : Produc- tion of pulmonary lesions and persistence of organisms and antibodies. Jpn. J. Vet. Sci., 36, 495503 .

[2] 跡部ヒサエ・尾形 学 (1977). マウスからのMycoplasma neurolyticum の分離とその病原性について。実験動物, 26, 301-308.

[ 3 ] Bhatt, P. N., and Jonas, A. M. (1974). An epizootic of Sendai infection with mortality in a barrier-maintained mouse colony. Amer. J. Epidemiol., 100, 222-229.

[4] Brennan, P. C., Fritz, T. E., and Flynn, R. J. (1969). Role of Pasteurella pneumotropica and Mycoplasma pulmonis in murine pneumonia. J. Bacteriol., 97, 337-349.

[ 5] Clyde, W. A. Jr. (1964). Mycoplasma species identification based upon growth inhibition by specific antisera. J. Immunol., 92, 958-965.

［6] 藤原公策・谷島百合子・田中正志 (1979). わが国におけ るマウス・ラットの生産群・実験群の 主要病原微生物に 対する抗体保有状況. 実験動物, 28, 297-306.

[7] Itoh, T., Kagiyama, N., lwai, H., Okada, O., Takashina, S., and Goto, H. (1978). Sendai virus infection in a small mouse breeding colony. Jpn. J. Vet. Sci., 40, 615-618.

[8] Iwai, H., Itoh, T., and Shumiya, S. (1977). Persistence of Sendai virus in a mouse breeder colony and possibility to re-establish the virus free colonies. Exp. Anim., 27, 17-20.

[9] 興水 䵅・曲淵輝夫・山本孝史・尾形 学 (1975). 輸入 サル類から 分離したマイコプラズマの性状. 実験動物, 24, 95-101.

[10] Nikaido, H., and Katagiri, K. (1969). Studies on respiratory infections of mice due to Mycoplasma pulmonis: Influence of various factors related to hosts. Jpn. J. Bacteriol., 24, 579-580.

[11] Saito, M., Nakayama, K., and Nakagawa, M. (1976). Localization of Mycoplasma pulmonis in mice. Exp. Anim., 25, 265-272.

[12] Saito, M., Nakagawa, M., Kinoshita, K., and Imaizumi, K. (1978). Etiological studies on natural outbreaks of pneumonia in mice. Jpn. J. Vet. Sci., 40, 283-290.

[13] Saito, M., Suzuki, E., Nakayama, K., Matsubara, J., and Nakagawa, M. (1980). An Attempt for eradication of Sendai virus from a mouse breeding colony. Exp. Anim., 29, 457-460.

[14] 東京大学医科学研究所学友会 (1971). 補体結合反応. 細 菌学実習提要, pp. 256-276, 医科学研究所学友会編, 丸 善, 東京. 